\title{
Erratum to: Analysis of miRNA-Mediated ceRNAs In The Pathogenesis of Renal Cell Carcinoma: An In Silico Approach
}

\section{Orcun AVSAR}

Hitit University, Department of Molecular Biology and Genetics, Corum, Turkey

\section{CAUSE OF ERRATUM}

The author recognized that some references are excluded and positioned in incorrect 1 places due to the reference manager software after the manuscript [E1] is published. Immediately, the author requested from the journal for the corrections of the errors as follows.
Article History:

Online: $2021 / 06 / 30$

Correspondence to: Orcun Avsar, Hitit University, Molecular Biology and Genetics, 19030, Corum, Turkey E-Mail: orcunavsar.gen@gmail.com Phone: $+90(364) 2271658$

\section{INTRODUCTION}

....... diseases such as cancer $[9,10$, E2].

........pathogenesis of diverse cancers [11, 12, E2, E3].

\section{MATERIAL AND METHODS}

... 'Verified Target Module' [E3, 13].

ceRNA activity of the defined miRNAs [E3, 14].

....... (in the exonic region) and downstream [E3, 15].

....... used for the analysis of gene expression [E2, E3, 16].

\footnotetext{
References

E1 Avsar O. Analysis of miRNA-Mediated ceRNAs in the pathogenesis of renal cell carcinoma: an in silico approach. Hittite Journal of Science and Engineering 7 (2020) 223-238.

E2 Altay DU, Ergun S. In silico analysis of biomarker potentials of miRNA-mediated ceRNAs in gastric neoplasms. Middle Black Sea Journal of Health Science 5 (2019) 106-119.

E3 Ergun S. In silico analysis of biomarker potentials of miRNAmediated ceRNAs in prostate cancer. Dicle Medical Journal 45 (2018) 415-429.
}

\section{Appendix}

Table A.2. The list of genes including T-UCR in their exonic regions according to the study [15]. 